\title{
VEGETATION IN INDIAN ART
}

\author{
Dr. Anjali Pandey $1 \bowtie$
}

${ }^{1}$ HOD, Drawing and Painting Department, Maharani Lakshmi Bai Government Girls Pg Auto College, Bhopal, M.P, India

\section{ABSTRACT}

Indian art is a vivid presentation of various forms of nature. In many ancient cultures trees are treated with acclaim and affection but in India treated with reverence and love. The concept of tree, as a symbol of life, of eternity and resumption is as old as humankind. The environmentalists evaluate their importance for the world's ecosystem as they are used in numerous ways in everyday life, but their aspect is that they are the symbol of divinity of nature with beauty and cultural values.

Nature with its qualities helps the creatures in their survival. The beauty of nature can be perceived in its utility and man can pay his attributes with the awareness towards the protection of nature.

Keywords: Primitive Fertility, Animism, Stylized Form

Received 06 May 2020

Accepted 16 June 2020

Published 27 June 2020

\section{Corresponding Author}

Dr. Anjali Pandey,

anjali_pandey11@yahoo.com

\section{DOI}

10.29121/shodhkosh.v1.i1.2020.8

Funding: This research received no specific grant from any funding agency in the public, commercial, or not-for-profit sectors.

Copyright: (C) 2020 The Author(s). This is an open access article distributed under the terms of the Creative Commons Attribution License, which permits unrestricted use, distribution, and reproduction in any medium, provided the original author and source are credited.

OPEN ACCESS

\section{INTRODUCTION}

"All great art owes the inspiration of religion. When spring comes, trees burst into blossoms. What spring is to the trees, inspiration is to the human race. All creative art activity, such as architecture, culture, painting, poetry and music is an expression of spiritual joy felt by sensitive people." Randhawa and Randhawa (1980)

The harmonic relation of man with nature is depicted throughout, in each and every era. The presence of a tree indicates water, growth, and fertility. They have an important place in the socio -religious life of India. The Indian artist expresses extraordinary interest in the depiction of nature from primitive to most cultured society.

Nature facilitated various forms and varieties of colors that inspired the man to explore and represent the artistic composition and designs forms.

The concept of animism is emphasized in Indian art; it helps the people to come close with one another with a deep sense of humanism that shows the intense awareness of unity of all life. Over the years, the wonders of the natural world, its evidence, and its representation, that others can recognize it, provides the visual narration with aesthetic satisfaction that is continuing. Art contributed the prime role. Much evidence is captured by the artists of cave painting to the present age. 


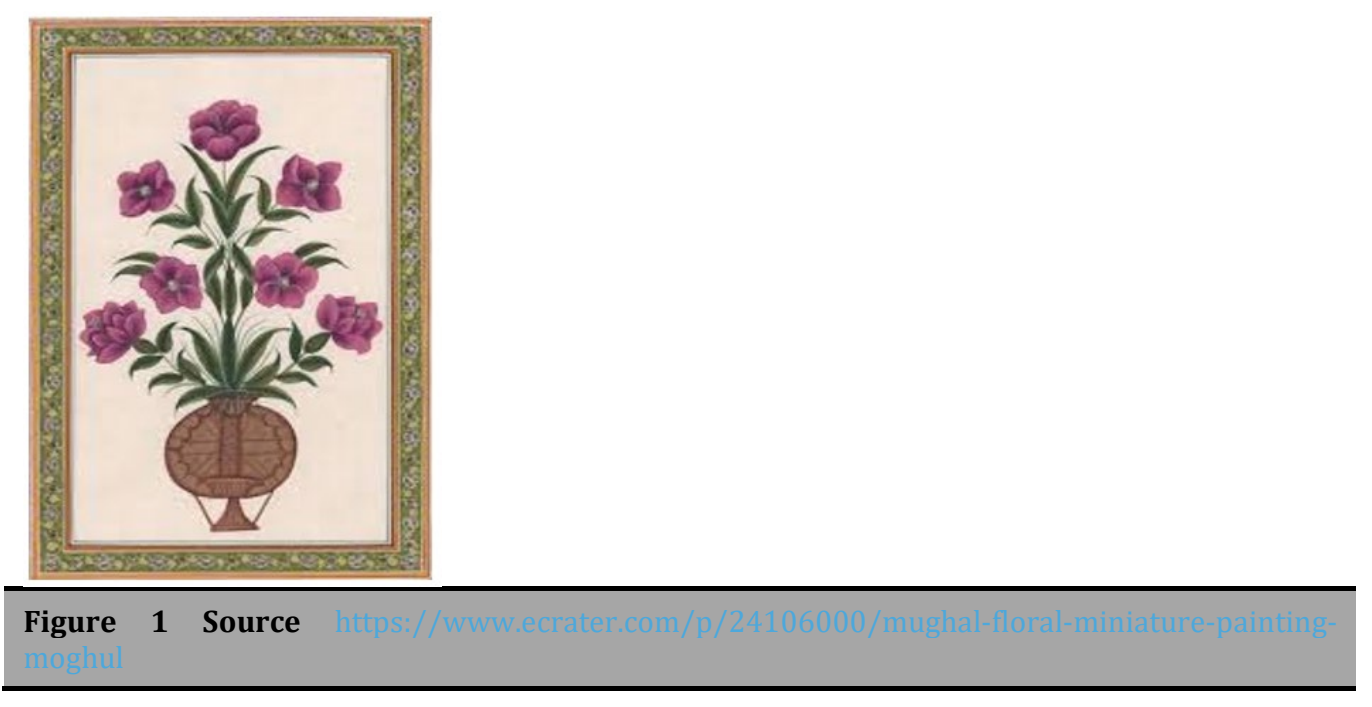

\section{PREHISTORIC AGE}

In many primitive paintings we see the worship of nature; vegetation is depicted in symbolic and stylized form. The early man was primarily dependent on forest and nature. The depiction of trees and plants are captured by him, but the vegetal representations are less than hunting scenes. There is a painting from Attala Kerala- a plant with many branches and full of leaves is growing in a pot. A bud is also depicted. White colour is used to fill the Figure 2. Mishra (2014)
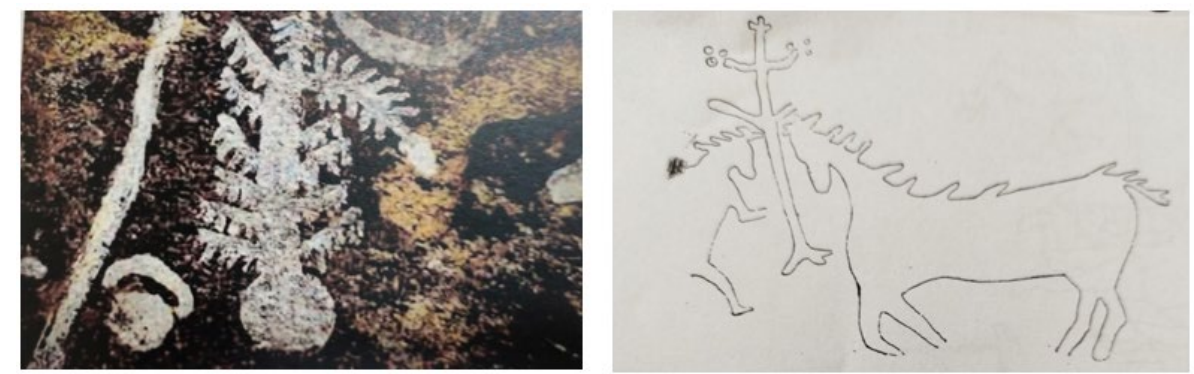

Figure 2 Source Mishra Anjali: Madhyapradesh ke Shailchitra:Ek kalatmak Addyan(kathotia evam jawra ke visheh sandarbh main -unpublished PhD Thesis B.U. 2015 ; Pg-470 Fig Pre Historic :courtsy Hemant Jain/ Jagdish Gupt

The other picture also shows a flowered tree in the centre, on the left side, Human figure with a horse face is depicted, which is not clearly visible and on the right side there is a horse figure. According to Sir Monier Williams the word 'Ashwath' originated from 'Ashwasth' which means the tree under which the horses were tied. The Ashwath tree is glorified in Indus, Vedic, and Buddhist traditions. Gupt (1967)

The plant motifs are encountered at almost all the chalcolithic sites. In the painted pottery of Indus Valley Civilization Palm and Pipal trees are depicted. The stylish Pipal Tree with two heads of unicorns emerging from its stem is engraved. Lal et al. (2014). Figure 3: 


\section{VEDIC PERIOD}

In Vedic period tree worshipping became quite common and occupied a very important place - in Puran also, the study of flora with the intention of finding out the improper utility has been done. There is a categorized reference to the name of sacred plants is mentioned in Karma Puram. The Taittiriya Upanishad suggests the Pipal Tree as the originator of the world tree. The uses of plants and their parts as flowers, leaves are also mentioned. Lal et al. (2014)

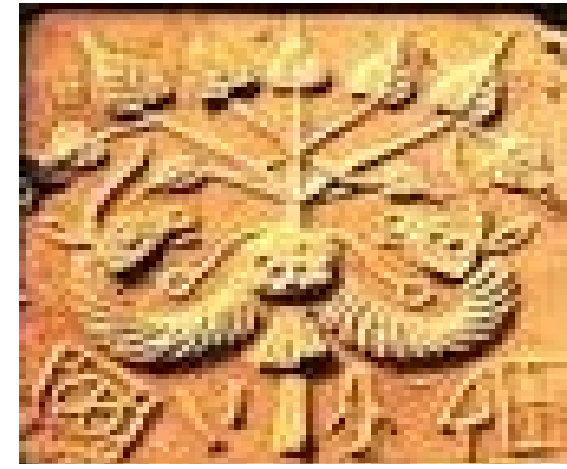

Figure 3 Source

\section{BUDDHIST PERIOD}

In Buddhist art the depiction of Bodhi tree implies a symbol of wisdom in Hinyan School. Gautama Buddha gained spiritual enlightenment while he was sitting under the Bodhi tree. Many great monuments of the time Bharhuth, Sanchi, Sarnath, Bodhgaya, Nagarjunakonda, Amravati, Ajanta and Mathura reflect the importance of vegetation. In Indian painting and sculpture, Ashoka tree, sal tree, coconut, mango, banana, sitaphal are commonly used to be engraved in the Buddist era.

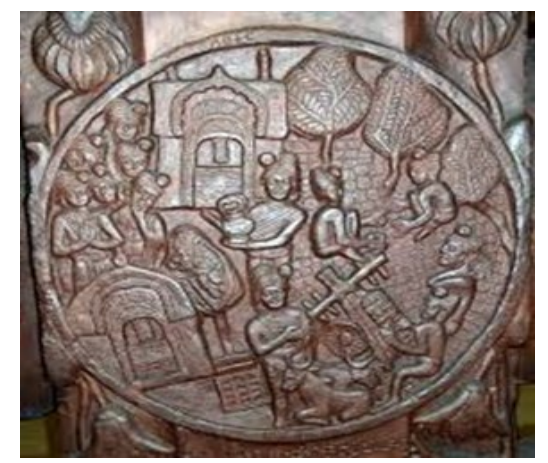

\section{Figure 4 Source}

Figure: Figure 4 In the Medallion Jetvan monastery depicts the story of a Merchant Anathapindika: he was interested to purchase a beautiful garden full of trees, named Jetvan for Gautam Buddha where he can deliver his preaches. The owner of the garden was not interested in selling that garden, so he asked for a high price and to cover the garden from the square gold coins as a purchasing cost. 
Anathpindak agreed on it and purchased the garden for Gautam Buddh. The story represents that nature is priceless. Mathur (1996)

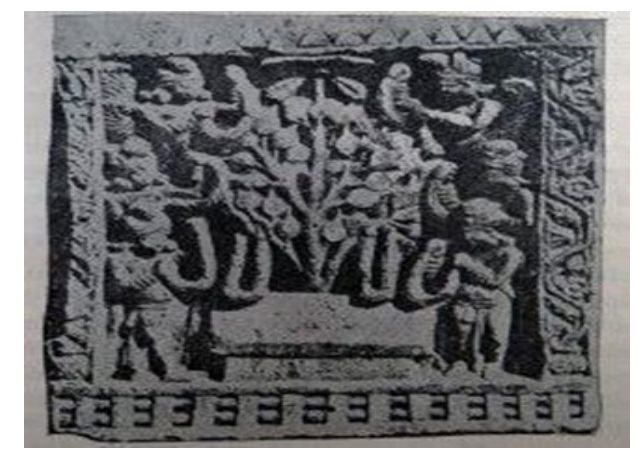

Figure 5 Source

Figure: Figure 5 The other Medallion is "Worship of Bodhi Vriksha" from Amravati, there is a group of worshipers with garlands in their hands worshipping the Bodhi tree. In Buddhist monuments nature is prominently represented in various forms, varieties of plants, trees, creepers, fruits, and flowers have taken place in symbolic and stylized manner. Buddhism Portal (2020)

\section{MEDIAEVAL PERIOD}

"From the ocean to the Himalayas, from the north to the south, and from the east to the west, the pictorial art of the miniature has been expressed by the means of a multitude of studios, styles and schools which have evolved with their own original features and particulars. Out of this wonderful production of painting spread out over the thousands of years, thousands of miniature and other works dating back 15 centuries have come down to us" Francis (1981)

Babur's Memoirs reveals Babur's interest in nature. In Babur Nama the artist depicted the varieties of trees, plants, and flowers. Trees like Mango, Banana, Imli, Mahua, Jamun, Jackfruit, Coconut, Guler, Amla, Date Palm, Orange, Lime, Jasoon, Kaner, Kewda is painted in the painting. In Mughal art the intricate patterns of floral designs represented the borders of miniature paintings. The Flora of a region explores interrelated aspects of religious, social, artistic, economic, and medical significance of plants. Randhawa and Randhawa (1980)

It is said that the world Conqueror Alexander discovered a talking tree that informed him of his impending Doom. This is depicted in paintings and textiles in Mughal Era. A painting from Golkunda in 17 century ADS, shows many human animal and reptile figures on a tree. Dhamija (2011).Figure 6 


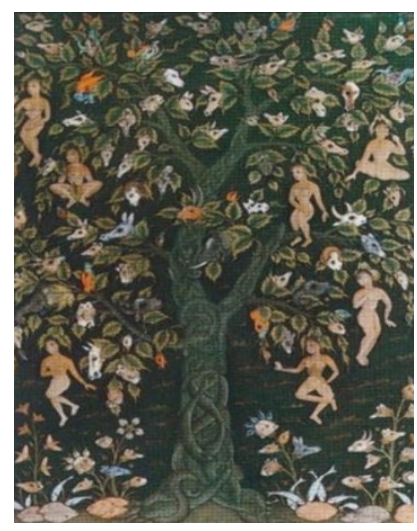

Figure 6 Source

\section{RAJPUT PAINTING}

Tropical India exhibits a distinctive literature of aesthetic beauty. The history of gardens in India goes around with the history of Arts like painting and architecture. As the greenery of the garden gives coolness it became more popular in Rajasthan.

Figure: This painting describes a white contrast marbled with the dark silhouettes of a tree. Figure 7

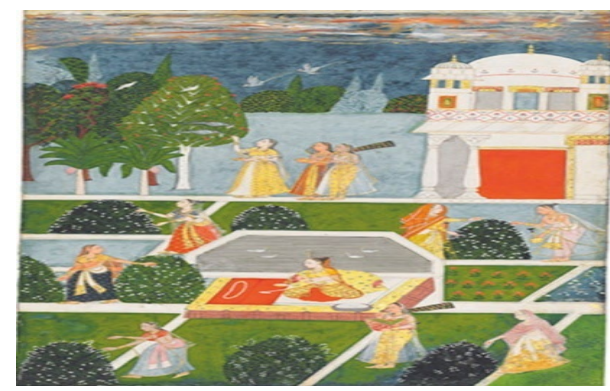

Figure 7 Source

\section{PAHARI PAINTING}

The natural landscape and the low hills of Himalayas served as a backdrop for Pahari miniature paintings. Sometimes it comes up as a complement to elements of the empty space of painting.

Figure: The depiction of Ram and Sita in dense forest during the exile has taken from the Pahari miniature painting and ancient texts. Artisera (2020)

Figure: This painting is from Kangra in this figure Radha- Krishna, Gap and Gopies are all together with their cows in the forest, in front part of the painting, a lotus- pond, full of flowers and leaves is visible. The artist depicts blossomed trees and greenery, sky is full of clouds and cranes are flying in a row. Kangra painting (2020). Figure 8 

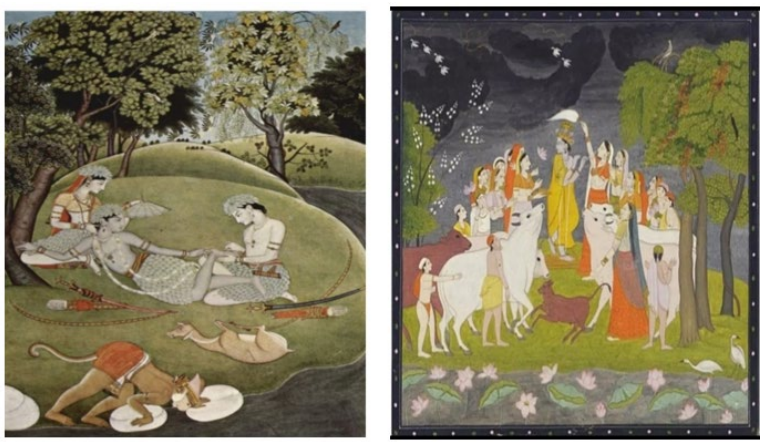

Figure 8 Source

\section{COMPANY SCHOOL}

Botanical representation in art seems more realistic, which was influenced by Europeans. In the 18th century at the time of East India Company a different style of miniature painting developed. The main subjects were the representation of Indian daily life portraits, and the studies of Natural life. The Britishers started to begin the documentation and record keeping. The artists from Mughal and Rajput courts were hired to paint the range art works to preserve the memories. These botanical arts visualize like visual aids for documentation. Many paintings represent the floral evidence of that time. Chheda (2019)

"Science, philosophy and art, all play a part in forming the images that they are transmitted through our culture. But art plays a most decisive role in transmitting it and making it persist. Sinha (1980). Figure 9
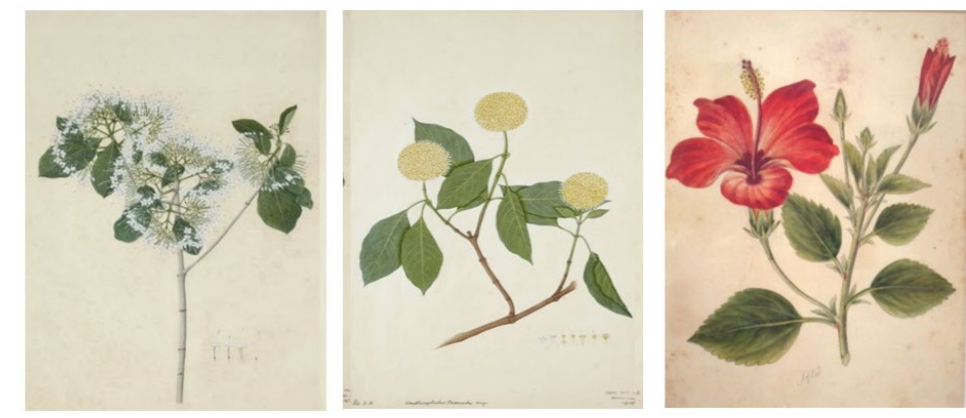

Figure 9 Source

\section{CONTEMPORARY ART}

Nature has always inspired humans. Our cultural heritage and paintings are maintaining antiquity through surroundings. The contemporary art is the art which produced in the second half of the 20th century or in the 21st century. Contemporary Art (2020) The experiments in technology have generated large dividends in visual variety. In Contemporary Indian art, many of the works are marked by distinct changes in style, techniques, expression, and other forms of artistic expressions. They are immediately connected with daily life activities, environment and physical surrounding with its various mood and Seasons 
The socio-political and industrial-economic changes helps India to come up as an emerging modern Nation. The influence of the British art school inspired many Indian artists, and it brought a change in the style of art. New educational patterns and syllabus were formed. Study of nature, still life, and landscape in a realistic manner were used as a part of art education. Figure 10

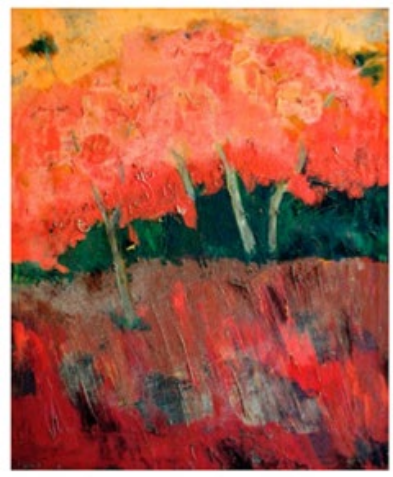

Figure 10 Source

\section{FOLK AND TRIBAL ART}

"The images that prevail and catch human imagination generally come through art, be it in the form of folk art, literature, painting, culture, architecture, and music. Sinha (1980)

As the time and evolution rendered the nomadic communities of India or tribals, settlements to communities and the changes of their lifestyle, can be clearly seen today in their paintings. From the basic hunting scenes to the settlement of communities, ritual for deities and nature can be noticed in their paintings. Gond art, Bhil, Warly art and other tribal paintings portrays the changes in their artwork.

Figure: Tribal Art- Three peacocks are sitting on a tree while one is on the ground. The artist used the multicoloured stylised form in his painting. The bunches of leaves are also multicoloured. Many of the tribal paintings are the harmonious representation of flora and fauna. Figure 11

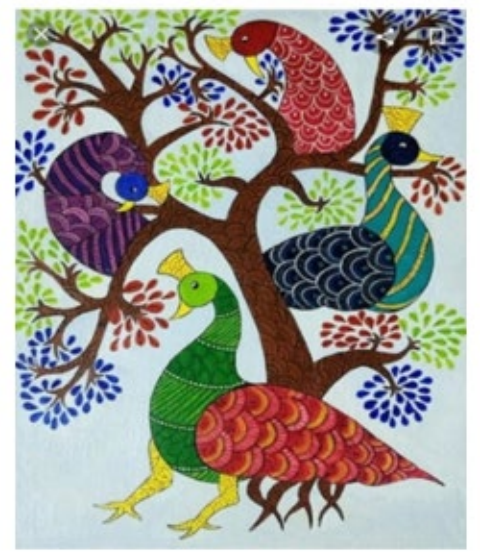

Figure 11 Source 
Folk and classical religion are enormously entwined in India, whereas the tree is considered as Purush and earth as Prakriti; this harmony creates life. In Indian culture folk beliefs and practices are imbibed with Hindu practices. Local and Puranic deities are worshipped all together. As the worship of trees, Sun, Moon, Bhoomi,Rivers, Agni( pancha tattwa), Kalash or Ghat, Swastik etc are common in both cultures. Pipal, Banyan(vat) Tulsi, Amla, Parijat, Kadamb,Shami are also worshipped in both the cultures. The rural folk art of India has great sensibility and potential.

Figure: Vat Poojan- In this Madhubani painting of Bihar, the Savitri Vrat has been depicted, in which women are worshipping 'Vat tree' for the long life of their husband. Figure 12

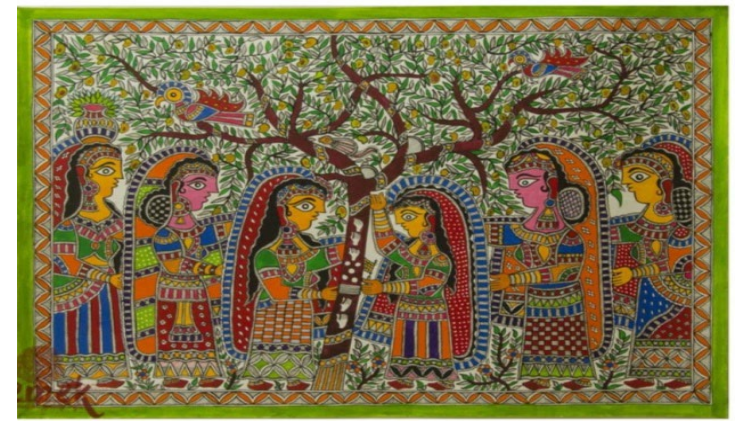

Figure 12 Source

\section{RANGOLI AND ALPANA ART} floor art.

In many parts of India, Floral motifs play a significant role for decoration in

In various festivals, Vegetative Motifs as lotus flowers, rose, sunflowers, Sadabahar, and other flowers, leaves, keri, Tulsi bush, in simplified and symbolic form are used to decorate the doors. Alpana (2020). Figure 13

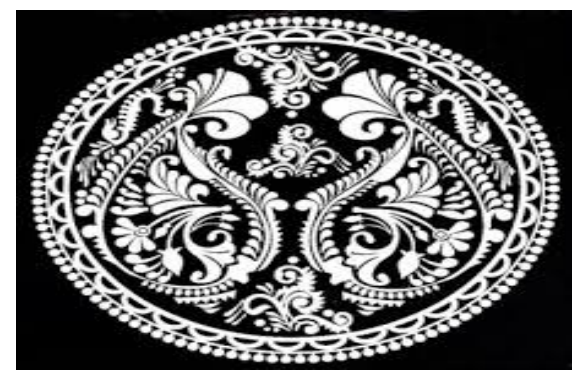

Figure 13 Source

\section{TEXTILES MOTIFS}

Motifs on carpets, embroidery designs, wood carvings, metal craft and Potteries represent the richness of vagital forms. many flowers, fruits, leaves, plants, and trees are used as motifs and patterns in weavings Carpetstry, embroidery. In

kashmiri shawls 'Tree of life', 'ambi or keri', etc are popular. In chikankari 'keri' 
design and floral motifs are mainly used as a design. Lotus or kamal is most popular in textiles, it is in various stylised, decorative, and simplified forms. In 'Kantha' embroidery work it is prominently represented. Figure 14

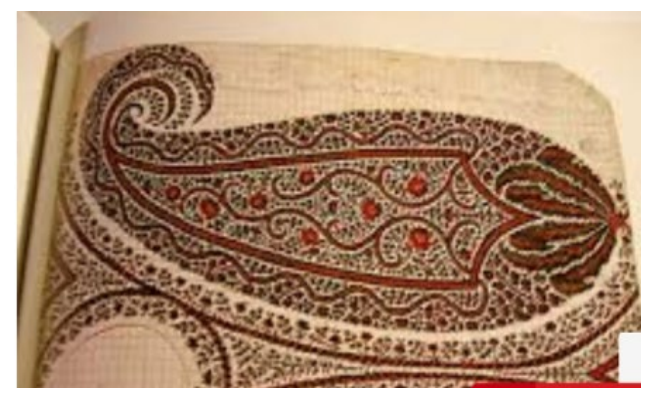

Figure 14 Source

Figure: In Kalamkari painting, the peacocks and birds are enjoying themselves on the flowered tree. In Indian art, peacocks and flowers are the symbols of joyfulness. Figure 15

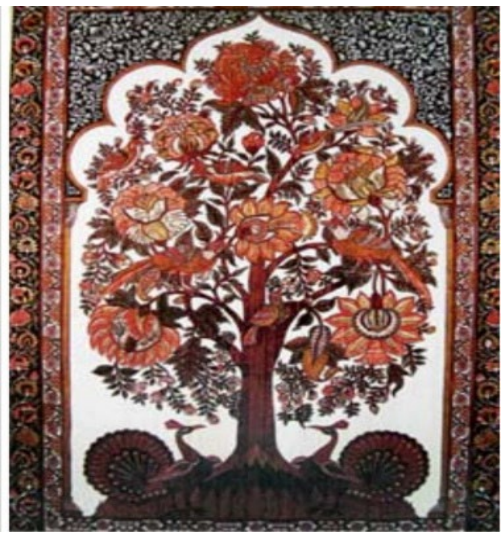

Figure 15 Source

\section{CONCLUSION}

In the entire Pictorial production of India tree appears constantly in almost all the forms of Indian art. In many cultures specific trees are the object of worship. In Hindu tradition the worship of trees expands to many real plants and trees.

The tree of life not only stands for the growth, escalation, and rejuvenation; it is associated with the infinite profusion of life reflecting eternity and resumption. the Babur Nama represents the truthful record of flora and fauna. Hence this can be seen since the very early till now that the vegetation has been depicted in each and every era. The depiction of nature is in human and symbolic form; they are the pioneers of social and life values. All these traditions have naturally spilled over in India. Figure 16 


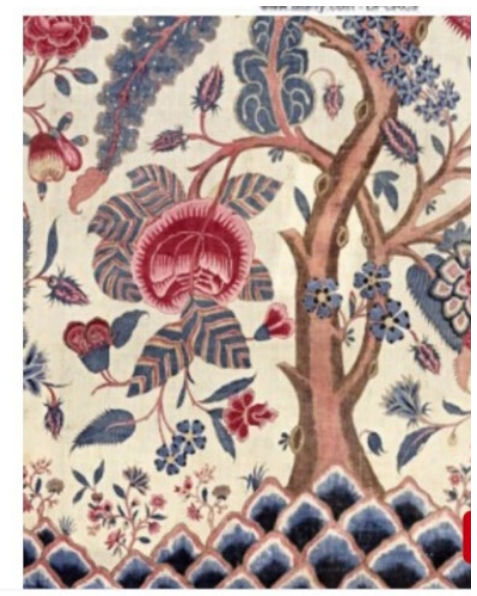

Figure 16 Source

\section{REFERENCES}

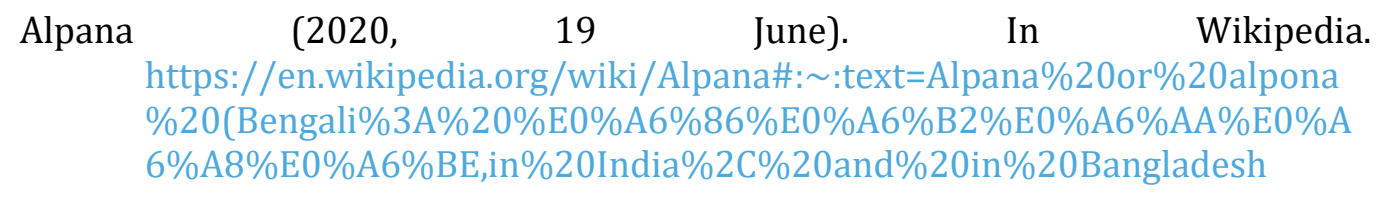

Artisera (2020, June 16). Old Indian Miniatures Remnants of The Past. https://www.artisera.com/collections/indian-miniatures

Buddhism Portal (2020, june 16). In Wisdom Library. https://www.wisdomlib.org/buddhism

Chheda, U. (2019, November 7). Company School - Transition to Indian Modern Art. Daily Art. https://www.dailyartmagazine.com/company-school-transitionto-indian-modern-art/

Contemporary Art (2020, 19 June). In Wikipedia. https://en.wikipedia.org/wiki/Contemporary_art

Dhamija, J. (2011, May 30). The Tree of Life. The Times of India. https://timesofindia.indiatimes.com/the-tree-oflife/articleshow/6893805.cms

Francis, B. (1981). The Splendour of Indian Miniatures. Editions Delroisse, Paris, 8. https://www.indianculture.gov.in/ebooks/splendour-indian-miniatures

Gupt, J. (1967). Pragaitihasik Bhartiya Chitrakala [Prehistoric Indian Painting]. National Publishing House, Delhi, 7, 414. https://archive.org/details/in.ernet.dli.2015.403154/page/n1/mode/2up
Kangra painting (2020, June 19). In Wikipedia. https://en.wikipedia.org/wiki/Kangra_painting

Lal, H. S., Singh, S., \& Mishra, P. K. (2014). Trees in Indian Mythology. Discovery, 12(29), 16-23.

https://www.discoveryjournals.org/discovery/current_issue/v1113/n25-34/A8.pdf 
Mathur, V. (1996). Art and culture under the Sungas (1st Ed.). Delhi : Bharatiya Kala Prakashan, 50 . https://primo.getty.edu/primoexplore/fulldisplay/GETTY_ALMA21122487750001551/GRI

Mishra, A. (2014). Madhyapradesh Ke Shailachitra. Ek Kalaatmak Adhyaan (Kathotiya Evam Javaara Ke Vishesh Sandharbh Main [Rock Paintings Of Madhya Pradesh. An Artistic Study (with special reference to Kathotia and Jawara)] [Unpublished PhD Thesis]. B.U. 470.

Randhawa, M. S. (1983). Paintings of the Babur Nama (1st Ed.). National Museum New Delhi. https://www.abebooks.com/first-edition/Paintings-BaburNama-Randhawa-M-S/22855393344/bd

Randhawa, M. S. and Randhawa, D. S. (1980). Kishangarh Painting, Vakils, Feffer \& Simons.

https://books.google.co.uk/books/about/Kishangarh_Painting.html?id=nu HqAAAAMAAJ\&redir_esc=y

Sinha, S. (1980). Chaos and Creation. Lalit Kala Academy, New Delhi. https://books.google.co.uk/books/about/Chaos_and_Creation.html?id=xZ CfAAAAMAAJ\&redir_esc $=y$ 